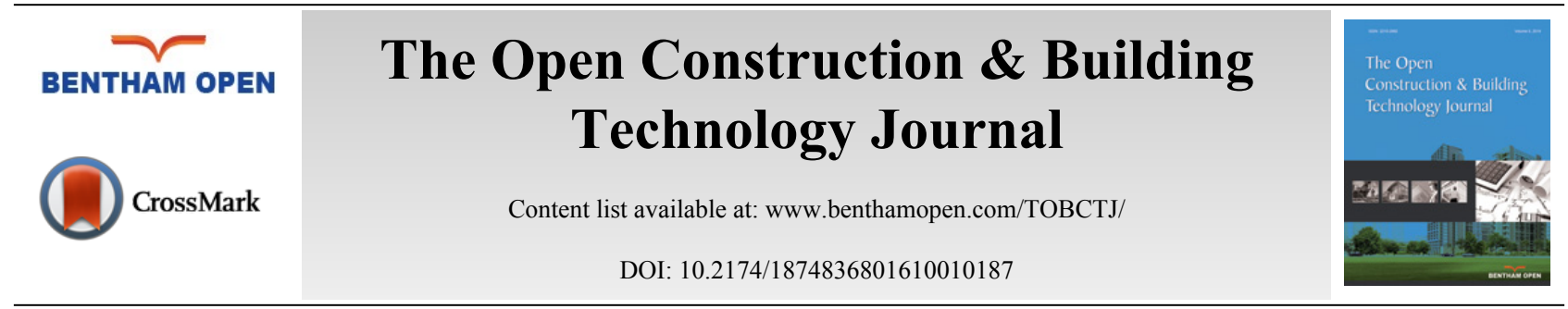

\title{
Retraction Notice: Research on Levying of Extending VAT Tax of Transportation Industry Based on Fuzzy TOPSIS
}

Wei Du*

Taiyuan Institute of Technology, Department of Economics and Management, Taiyuan, 030008, China

\section{RETRACTION}

The Publisher and Editor have retracted this article [1] in accordance with good ethical practices. After thorough investigations we believe that the peer review process was compromised. The article was published online on 19-08-2015.

\section{REFERENCE}

[1] W. Du, "Research on Levying of Extending VAT Tax of Transportation Industry Based on Fuzzy TOPSIS", Open Constr. Build. Technol. J., vol. 9, pp. 87-91, 2014.

(C) Wei Du; Licensee Bentham Open.

This is an open access article licensed under the terms of the Creative Commons Attribution-Non-Commercial 4.0 International Public License (CC BY-NC 4.0) (https://creativecommons.org/licenses/by-nc/4.0/legalcode), which permits unrestricted, non-commercial use, distribution and reproduction in any medium, provided the work is properly cited.

* Address correspondence to this author at the Taiyuan Institute of Technology, Department of Economics and Management, Taiyuan, 030008, China; Tel: 13754888811; E-mail: dw6124@163.com; 